\title{
POSISI DAN PERAN GURU DALAM POLA KURIKULUM 2013
}

\author{
Anas Suprapto \\ Pengawas MTs. di Pasuruan \\ e-mail: anassuprapto2073@gmail.com
}

\begin{abstract}
The Changes to a curriculum will undoubtedly continue to occur. The big mission of these changes alone is in order to create a better situation for the out put of education. Such changes substantially in order to strike a balance between the spiritual and social attitudes, curiosity, creativity, cooperation with intellectual and psychomotor abilities. Curriculum 2013 appears to create output that is expected of it. To reach it, one fundamental factor is the maximization of the candidates' professional aptitude of teachers as an important instrument for the success of education. The application of research-based learning can be used to develop self-potential students in this controversial curriculum.
\end{abstract}

Keywords: teacher, student, curriculum 2013, research

\begin{abstract}
Abstrak: Perubahan pada sebuah kurikulum niscaya akan terus terjadi. Misi besar dari perubahan ini sendiri adalah supaya tercipta situasi yang lebih baik bagi out put pendidikan. Perubahan tersebut secara substansial dalam rangka keseimbangan antara sikap spiritual dan sosial, rasa ingin tahu, kreativitas, kerja sama dengan kemampuan intelektual dan psikomotorik. Kurikulum 2013 muncul agar tercipta out put yang diharapkan itu. Untuk menuju hal itu, salah satu faktor mendasar adalah maksimalisasi terhadap pembekalan calon tenaga profesional guru sebagai instrumen penting dalam menyukseskan pendidikan. Penerapan pembelajaran berbasis riset bisa digunakan untuk mengembangkan potensi diri siswa dalam kurikulum yang menuai kontroversi ini.
\end{abstract}

Kata-Kata kunci: guru, siswa, kurikulum 2013, penelitian

\section{Pendahuluan}

Berdasarkan Surat Edaran Nomor 179342/ MPK/ KR/ 2014, Menteri Pendidikan Dasar dan Menengah dan Kebudayaan melakukan penghentian sementara pelaksanaan kurikulum 2013 sampai tanggal 15 Desember 2014. Surat ditujukan secara langsung kepada Kepala Sekolah di seluruh Indonesia. Memperkuat Surat Edaran tersebut, pada 
11 Desember 2014 Menteri Pendidikan \& Kebudayaan Nomor 160 Tahun 2014 tentang Pemberlakuan Kurikulum 2006 dan Kurikulum 2013 yang segera ditindaklanjuti dengan Peraturan Bersama Direktur Jenderal Pendidikan Dasar dan Direktur Jenderal Pendidikan Dasar dan Direktur Jenderal Pendidikan Menengah Nomor 5496/ C/ KR/ 2014 dan Nomor 7915/ D/ KR/ 2014 tentang Petunjuk Teknis Pemberlakuan Kurikulum 2006 dan Kurikulum 2013 pada Sekolah Jenjang Pendidikan Dasar dan Pendidikan Menengah.

Pelaksanan Kurikulum 2013 memang menyisakan beberapa masalah konseptual yang dihadapi, mulai dari ketidakselarasan antara ide dengan desain kurikulum hingga ketidakselarasan gagasan dengan isi buku teks. Sementara itu, masalah teknis penerapan seperti berbeda-bedanya kesiapan sekolah dan guru, belum merata dan tuntasnya pelatihan guru dan kepala sekolah, serta penyediaan buku pun belum tertangani dengan baik. Anak-anak, guru, dan orang tua pula yang akhirnya harus menghadapi konsekuensi atas ketergesagesaan penerapan sebuah kurikulum. Segala permasalahan itu memang ikut melandasi pengambilan keputusan terkait penerapan Kurikulum 2013 ke depan, namun yang menjadi pertimbangan utama dalam pengambilan keputusan ini adalah kepentingan peserta didik.

Berdasarkan realitas tersebut dan dengan memperhatikan rekomendasi tim evaluasi implementasi kurikulum, serta diskusi dengan berbagai pemangku kepentingan, Menteri memutuskan beberapa hal: Pertama, menghentikan pelaksanan kurikulum 2013 di sekolah-sekolah yang baru menerapkan satu semester, yaitu sejak tahun pelajaran 2014/2015. Sekolah-sekolah ini supaya kembali menggunakan Kurikulum 2006. Kedua, tetap menerapkan kurikulum 2013 di sekolah-sekolah yang telah tiga semester ini (dihitung sampai akhir semester ganjil 2014 kemarin) menerapkan, yaitu sejak tahun pelajaran 2013/2014, dan menjadikan sekolah-sekolah tersebut sebagai sekolah pengembangan dan percontohan penerapan kurikulum 2013. Namun hal tersebut dikecualikan bagi sekolah yang keberatan menjadi sekolah pengembangan dan percontohan kurikulum 2013, dengan alasan ketidaksiapan dan demi kepentingan siswa, dapat mengajukan diri kepada Kemendikbud untuk 
penghentiannya. Ketiga, mengembalikan tugas pengembangan Kurikulum 2013 kepada Pusat Kurikulum dan Perbukuan, Kementerian Pendidikan dan Kebudayaan RI. Pengembangan kurikulum tidak ditangani oleh tim ad hoc yang bekerja jangka pendek.

\section{Konsep Pengembangan Kurikulum}

Menurut Nasution (dalam Ahmad, 1998: 10), istilah kurikulum berasal dari atletik, yaitu curere yang berarti berlari. Dari istilah atletik inilah, kurikulum kemudian mengalami pergeseran arti ke dunia pendidikan, yakni sejumlah mata pelajaran di perguruan tinggi.

Menurut Muhaimin (2003: 182), pengertian kurikulum dalam arti yang sempit merupakan seperangkat rencana dan pengaturan tentang isi dan bahan pelajaran serta cara yang digunakan sebagai pedoman penyelenggaraan kegiatan belajar mengajar di sekolah. Pengertian ini mengarisbawahi adanya 4 (empat) komponen pokok dalam kurikulum, yaitu tujuan, isi/ bahan, organisasi dan strategi. Sementara itu, dalam pengertian secara luas, kurikulum merupakan segala kegiatan yang dirancang oleh lembaga pendidikan untuk disajikan kepada peserta didik guna mencapai tujuan pendidikan (institusional, kurikuler, dan intruksional).

Pengertian kurikulum sebagaimana tercantum dalam UUSPN No.20 Tahun 2003 adalah sebagai seperangkat rencana dan pengaturan mengenai tujuan, isi, dan bahan pelajaran serta cara yang digunakan sebagai pedoman penyelenggaraan kegiatan pembelajaran untuk mencapai tujuan pendidikan tertentu (UUSPN, No. 20 Tahun 2003, Bab 1 Ayat 19).

Adapun pengembangan kurikulum (curriculum development) menurut Audrey Nicholls dan S. Howard Nichools adalah: the planning of learning opportunities intended to bring about certain desered in pupils, and assessment of the extent to wich these changes have taken plece (Hamalik, 2006: 96). Berdasarkan rumusan tersebut, dapat diketahui bahwa pengembangan kurikulum adalah perencanaan kesempatan-kesempatan belajar yang dimaksudkan untuk membawa siswa ke arah perubahan-perubahan yang diinginkan dan menilai hingga mana perubahan-perubahan itu telah terjadi pada diri siswa. 
Dalam pengertian itu, sesungguhnya pengembangan kurikulum adalah proses siklus, yang tidak pernah berakhir.

\section{Prinsip Pengembangan Kurikulum}

Prinsip umum pengembangan kurikulum menyangkut lima hal. Berikut lima hal yang menjadi prinsip-prinsip umum tersebut (Sukmadinata, 2005: 151):

\section{Prinsip Relevansi}

Ada dua macam relevansi yang harus dimiliki kurikulum, yaitu relevansi keluar dan relevansi di dalam kurikulum itu sendiri. Relevansi keluar maksudnya adalah tujuan, isi, dan proses belajar yang tercakup dalam kurikulum hendaknya relevan dengan tuntutan, kebutuhan, dan perkembangan masyarakat. Kurikulum juga harus memiliki relevansi di dalam, yaitu ada kesesuaian atau konsistensi antara komponen-kompoenen kurikulum, yaitu antara tujuan, isi, proses penyampaian, dan penilaian. Relevansi internal ini merupakan suatu keterpaduan kurikulum.

2. Prinsip Fleksibilitas

Prinsip fleksibilitas menunjukkan bahwa kurikulum adalah tidak kaku. Hal ini berarti bahwa di dalam penyelenggaraan proses dan program pendidikan harus diperhatikan kondisi perbedaan yang ada di dalam diri peserta didik (Ahmad, 1998: 71).

3. Prinsip Kontinuitas

Prinsip kesinambungan dalam pengembangan kurikulum menunjukkan adanya saling terkait antara tingkat pendidikan, jenis program pendidikan, dan bidang studi (Ahmad, 1998: 71).

4. Prinsip Praktis

Kurikulum harus mudah dilaksanakan, menggunakan alat-alat sederhana dan biayanya juga murah. Prinsip ini juga disebut prinsip efesiensi (Sukmadinata, 2005: 151). Efisiensi merupakan perbandingan antara hasil yang dicapai dan pengeluaran (berupa waktu, tenaga, dan biaya) yang diharapkan paling tidak menunjukkn hasil yang seimbang (Ahmad, 1998: 70).

5. Prinsip Efektivitas 
Dalam dunia pendidikan, masalah efektivitas dapat ditinjau dari segi efektifitas mengajar guru dan efektifitas belajar murid. Efektivitas mengajar guru menyangkut sejauh mana jenis-jenis kegiatan mengajar yang direncanakan dapat dilaksanakan dengan baik. Efektivitas belajar murid menyangkut sejauh mana tujuan-tujuan pelajaran yang diinginkan dapat dicapai melalui kegiatan belajar mengajar yang ditempuh (Ahmad, 1998: 117).

\section{Posisi Guru dalam Situasi Kurikulum yang Berubah-Ubah}

Guru adalah unsur manusiawi dalam pendidikan. Guru merupakan figur manusia sebagai salah satu sumber yang menempati posisi dan memegang peranan penting dalam dunia pendidikan. Ketika semua orang mempersoalkan masalah dunia pendidikan, figur guru meski terlibat dalam agenda pembicaraan terutama yang menyangkut persoalan pendidikan formal di sekolah (Djamarah, 2005: 1).

Dalam bahasa Arab, guru dikenal dengan istilah al-mu'alim atau al- ustadz yang bertugas memberikan ilmu dalam majelis taklim (tempat memperoleh ilmu). Dengan demikian, guru dapat diartikan sebagai orang yang tugasnya terkait dengan upaya mencerdaskan kehidupan bangsa dan semua aspeknya, baik spiritual, emosional, intelektual, fisikal, maupun aspek lainnya (Suparlan, 2005: 11-12).

Guru tidak hanya dituntut memiliki kemampuan mentransformasikan pengetahuan yang dimilikinya dan memberikan ketauladanan pengalaman, tetapi juga diharapkan mampu menginspirasi anak didiknya agar mereka dapat mengembangkan potensi diri dan memiliki akhlak yang baik. Dalam menghadapi perkembangan zaman yang begitu pesat, pemerintah Indonesia bertekad untuk meningkatkan mutu pendidikan dengan salah satunya merancang kurikulum 2013 yang begitu heboh ketika diluncurkan. Hampir setiap guru mengikuti kegiatan worksop dan hanya sedikit yang belum mengikutinya. Kurikulum 2013 diharapkan mampu memberikan kontribusi yang lebih baik untuk peningkatan kualitas pendidikan di Indonesia. Tetapi kenyataannya masih banyak di antara para guru mengalami kesulitan dalam tataran implementasinya, sehingga pada akhirnya menunculkan wacana agar kurikulum dikembalikan kepada kurikulum 2006. Wacana inipun menimbulkan 
pro dan kontra, ada yang setuju untuk tetap melanjutkan kurikulum 2013, tetapi banyak yang setuju untuk dikembalikan kepada kurikulum 2006. Perbedaan seperti itu wajar karena masing-masing mempunyai argumentasi sendiri-sendiri yang didukung dengan kelebihan dan kekurangannya. Terlepas dari itu semua, harus diingat bahwa apapun bentuk kurikulumnya guru harus tetap berkualitas.

Peningkatan kualitas guru merupakan kegiatan yang dilakukan untuk menambah atau meningkatkan pengetahuan, keterampilan, sikap, dan kepribadian yang utuh, sehingga tenaga kependidikan seharusnya memiliki karakteristik yang sesuai dengan tugas pokoknya yang terinternalisasi dalam kehidupan sehari-hari.

Dalam hal ini, lembaga pendidikan dihadapkan kepada tantangan, bagaimana agar pelaksanan pendidikan dan pembelajaran khususnya pendidikan agama tetap menarik perhatian siswa dan dirasakan relevan dalam kehidupan masyarakat yang terus berubah. Perubahan masyarakat semakin lama semakin cepat dan kompleks sehingga memerlukan suatu perenungan yang mendalam, khususnya bagi tenaga kependidikan dalam memberikan layanan kepada siswa.

Upaya untuk peningkatan kualitas tenaga kependidikan di sekolah menurut Dirjen Baga (2005:77-78), bisa dilakukan dengan dua cara, yaitu : pertama, dari pihak tenaga kependidikan itu sendiri, artinya seorang tenaga pendidikan harus benar-benar memiliki motivasi, tekad dan semangat yang besar untuk mengabdi dan melaksanakan tugas mendidik dan mengajar bagi bangsanya. Pendidikan harus pula memiliki kesadaran bahwa profesi guru adalah profesi yang paling luas bidang garapan dan tanggung jawabnya dari seluruh profesi dan dasar bagi seluruh profesi yang lainnya. Kedua, dari pihak luar tenaga kependidikan maksudnya pemegang kebijakan dengan memberikan pelatihan dan pengembangan, misalnya on the job training, yaitu tenaga kependidikan senior diminta untuk melatih para staf yunior (tenaga guru) langsung dalam kondisi kerja. Bisa juga job rotation, yaitu pemindahan tugas secara periodik dari tugas satu ke tugas lainnya. Ataupun misalnya, juga mengikutkan berbagai kegiatan yang bersifat akademik maupun non akademis misalnya pendidikan 
formal jenjang S.1, S.2, S.3, diklat, penataran, seminar, lokakarya, dan workshop.

Memang tidak mudah, karena upaya untuk menjadikan seseorang tenaga pendidik atau guru berkualitas atau profesional tentu harus didukung dengan faktor pendorong. Menurut Dirjen Baga (2005:84), untuk menjadi guru yang berkualitas atau profesional harus didukung beberapa hal, misalnya adanya motivasi yang tinggi dalam menjalankan profesi kependidikannya, terampil membelajarkan ilmu berdasar kemajuan tingkat-tingkat kognitif, afektif, dan psikomotorik siswa, memahami bahaya dehumanisasi, perbudakan, dan keberhalaan yang terkandung di dalam benda-benda teknologi, serta pendidikan berlangsung sepanjang hayat dan secara komplementer pada bidang ilmu, kesenian, dan kesusilaan. Jika tenaga pendidikan memperhatikan beberapa faktor pendukung tersebut, tidak mustahil pelaksanaan pendidikan dan pembelajaran di sekolah akan berjalan lancar. Sebagai hasilnya, siswa akan menjadi manusia-manusia cerdas terampil, berbudi pekerti luhur dan bermoral.

Kembali pada substansi Kurikulum 2013, guru sebagai pelaku utama bagi keberhasilan penerapan K-13, pemahaman guru yang memadai terhadap K-13, terutama bagaimana proses pengelolaan kelas harus benar-benar mencerminkan ruh K-13. Tentu saja hal ini kembali pada kemauan dan kemampuan guru untuk segera beradaptasi dengan keberadaan K-13, baik menyangkut hakekat perubahan K-13 maupun menyangkut pola penyajian K-13 dalam proses belajar mengajar. Masalah yang pasti akan muncul, apabila guru tetap berpola pada kebiasaan cara mengajar sebelumnya yang mengakibatkan peran aktif siswa menjadi terbatas.

Namun demikian, bukan berarti guru hanya memberi tugas dan tidak ada pantauan bagaimana siswa mengerjakan tugas-tugas yang diberikan. Sebab dengan pendekatan saintifik guru juga harus aktif, mengamati dan menilai sikap siswa selama pembelajaran. Kalau tidak, maka perubahan yang diinginkan oleh K-13 sulit tercapai. Belum lagi sejauh mana pemahaman guru dalam pembuatan soal tes, dan teknik evaluasinya, serta bagaimana pembuatan deskripsi bagi tiap siswa dalam rapor. 
Ada lima kompetensi yang harus dimiliki oleh guru profesional, yaitu kompetensi pedagogik, kompetensi profesional, kompetensi kepribadian, kompetensi sosial, dan kepemimpinan. Kompetensikompetensi tersebut sangat dibutuhkan untuk keberhasilan implementasi dan keterlaksanaan kurikulum 2013. Guru sebagai ujung tombak penerapam kurikulum, diharapkan bisa menyiapkan dan membuka diri terhadap beberapa perubahan yang terjadi pada K-13.

Belum atau sudah mendapatkan pelatihan, guru harus segera beradaptasi dengan perubahan yang terjadi pada K-13. Utamanya menyangkut bagaimana mengelola dan menyajikan setiap materi pelajaran seperti yang dikehendaki K-13, menjadikan kesiapan guru sebagai eksekutor K-13 menjadi vital. Dengan demikian, guru benarbenar dituntut mampu mendorong peserta didik dalam melakukan observasi, bertanya, bernalar, dan mengkomunikasikan (mempresentasikan) terhadap apa yang mereka peroleh atau mereka ketahui setelah menerima materi pembelajaran.

Dalam rangka kepentingan tersebut, upaya peningkatan kompetensi guru agar mampu menjadi ilmuwan dengan sikap ilmiah menjadi hal yang penting dan mendesak agar keterlaksanaan kurikulum 2013 sesuai dengan yang diharapkan. Hal ini penting agar guru dalam memberikan kebebasan pada siswa untuk mencari tahu dari berbagai sumber belajar tidak menjadi kebebasan yang justru akan mengacaukan pengamatan yang diperoleh. Dengan demikian, pendekatan saintifik dipersyaratkan K-13 tetap berada dalam bingkai keilmuan. Dalam posisi inilah, guru bukan sekedar mengajar dengan menyampaikan tugas-tugas seperti yang tertuang di dalam buku ajar tetapi guru sekaligus menjadi kurikulum hidup.

Kualitas pendidikan sangat tergantung pada kehebatan guru. Murid-murid di sekolah/ madrasah bisa menjadi hebat kalau guru-guru yang mengajar juga hebat. Karena itu, jika sekolah/madrasah ingin hebat dan bermutu, maka guru-gurunya harus "direkayasa" agar menjadi guru yang hebat (http://jatim.kemenag.go.id, 2 Januari 2014).

Pernyataan di atas ada benarnya dengan asumsi bahwa anakanak bangsa bisa menjadi hebat apabila proses pembelajaran yang 
dijalani di sekolah/madrasah dikelola guru-guru yang hebat pula. Pertanyaannya adalah, apakah selama ini para guru yang berada di garda depan pendidikan belum memiliki preofesionalisme yang hebat sehingga masih perlu terus dipacu kompetensinya?

Kurikulum K-13 secara substantif menerapkan pembelajaran berbasis riset. Dengan jargon 5M (mengamati - menanya - menalar mengaosiasi - dan mengkomunikasi). Dimulai dari langkah pembelajaran taktis melalui pengamatan dari suatu kejadian dan peristiwa (biasanya dengan diputarkan video oleh guru), kemudian proses pembelajaran dilanjutkan dengan menanya dan menalar. Kegiatan berikutnya mengaosiasi hasil pembelajaran untuk kemudian dikomunikasikan dalam sistem jejaring. Sebuah konsep baru yang cukup berani dan kini coba diterapkan di seluruh Indonesia, diharapkan mampu dan dapat mencetak produk berupa siswa agar proses pembelajaran mendatang menjadi lebih baik dan berkarakter.

Pemberlakuan konsep baru berupa K-13 itu diharapkan tidak hanya sebagai sarana ampuh menambah wawasan keilmuan bagi guru dan praktisi pendidikan saja, tetapi juga menjadi wadah komunikasi baru antara pemangku kebijakan, guru dan siswa.

Berawal dari pemikiran, konsep, dan permasalahan itulah sesungguhya salah satu syarat untuk meningkatkan kualitas pendidikan di Indonesia dari ketertinggalan dan keterpurukan, lantaran sistem pendidikan dan pengajaran yang dianut bangsa Indonesia masih enggan meningggalkan sistem konvensional atau "teks book". Para penentu kebijakan pendidikan nasional serta mayoritas guru belum siap dan mampu melepaskan perspektif mereka dari kebiasaan usang yang sudah ketinggalan zaman (out of date), yaitu era yang lebih meninabobokkan guru karena maunya guru itu tetap disuapi. Dampak yang terjadi adalah guru-guru menjadi terlena di "zona nyaman" (comfort zone).

\section{Berbasis Riset}

Tawaran alternatif berupa K-13 sebagai jawaban atas adanya rekonstruksi mendasar dalam proses pembelajaran yang diberikan kepada siswa, agar mereka lebih fokus pada sistem yang lebih praktis. Salah satu konsep yang bisa diterapkan oleh guru untuk 
mengembangkan potensi dirinya adalah dengan menerapkan pembelajaran berbasis riset (penelitian). Beberapa sekolah dan madrasah di Jawa Timur contohnya, mulai sebagian yang memberlakukan ini.

Konsep pembelajaran ini mestinya bisa dijalankan lebih efektif dan efisien karena bisa mencakup empat-lima mata pelajaran dalam sebuah proses penelitian. Misalnya, kita mengajarkan dan meminta peserta didik untuk mengajarkan sekaligus menindaklanjutinya dengan melakukan penelitian berupa menanam cabai.

Dengan pembelajaran yang sekaligus dijadikan objek penelitian berupa penanaman cabai tersebut, setidaknya didapatkan cakupan lima mata pelajaran yang dapat terangkum. Pertama, mata pelajaran biologi (IPA), melalui proses penanaman cabai saja siswa dihadapkan pada permasalahan tanah seperti apa yang layak untuk dipakai untuk menanamnya. Di samping itu, pupuk yang digunakan juga tidak sembarang pupuk. Melalui bimbingan guru IPA, para siswa akan mengetahui semua permasalahan itu dengan baik.

Kedua, mata pelajaran matematika. Guru dapat meminta siswa mengkalkulasi dengan perhitungan yang tepat sampai berapa besar biaya yang harus dikeluarkan mulai dari penanaman hingga proses panen. Kemudian dibandingkan dengan harga jual cabai hasil panen. Apakah proses berkebun siswa menuai hasil yang memuaskan atau tidak.

Ketiga, mata pelajaran pendidikan moral dan pengembangan karakter. Tentu proses ini tidak bisa dilalui sendiri, perlu kerja sama antar masing-masing siswa. Dari kerjasama tersebut, guru dapat menilai kejujuran, kedisiplinan, hingga ketekunan siswa. Perlu dicatat bahwa objek penelitian harus sesuai dengan kondisi sosial siswa. Di sini, guru dituntut menjadi pihak kreatif dan inovatif. Mereka harus mampu menguasi objek penelitian dengan baik. Bahkan bila perlu, guru harus menemukan terobosan baru tentang objek yang diteliti.

Keempat, mata pelalajaran ilmu pengetahuan sosial. Setelah penanaman berbuah dan siap panen, sistem pemasaran setelah memanen, siapa yang akan melakukan proses penjualan dari hasil petik? Langkah penjualan dan pemasaran ini menjadikan siswa bisa 
lebih paham dengan kondisi lingkungan masyarakat yang marginal sekaligus sebagai ajang komunikasi efektif sebagai dasar hidup di masyarakat kelak. Kelima, mata pelajaran pendidikan jasmani, olah raga, dan kesehatan. Dengan belajar menjadi seorang petani yang aktivitasnya banyak dilakukan dalam bentuk gerak badan atau olahraga (mencangkul dan menanam), diharapkan unsur kebugaran siswa tetap terjaga. Melalui konsep pembelajaran berbasis riset ini, pendidikan menjadi lebih membumi. Artinya, pendidikan mampu menjawab tantangan yang kini mutlak dibutuhkan di lingkungan masyarakat. Selain itu, juga membekali siswa-siswa dengan keterampilan, keleluasaan pandangan, dan memiliki pemikiran yang terkonsep untuk masa depan mereka. Bukan tidak mungkin pula, dari konsep pembelajaran yang berbasis riset ini akan muncul penemuanpenemuan baru dari hasil penelitian siswa.

\section{Sosok Guru yang Diinginkan}

Kurikulum 2013 diterapkan dengan tujuan untuk mempersiapkan manusia Indonesia agar memiliki kemampuan hidup sebagai pribadi dan warga negara yang beriman, produktif, kreatif, inovatif dan efektif, serta mampu berkontribusi dalam kehidupan bermasyarakat, berbangsa dan bernegara serta peradaban dunia. Untuk mempersiapkan manusia Indonesia di atas, dibutuhkan guru profesional yang mandiri. Guru profesional yang mandiri, adalah guru yang selalu mengajukan pertanyaan, mencoba ide-ide baru dan terus meningkatkan keefektifan diri sendiri. Guru ini tidak bergantung pada orang lain untuk memulai perubahan. Guru yang semodel itu adalah orang yang belajar sepanjang hidupnya. Guru profesional yang mandiri memelihara suatu standar yang jelas bagi diri mereka sendiri, memegang teguh idealismenya, mengetahui arah yang ingin mereka tuju dan mengetahui dengan segera jika mereka keluar jalur.

Ada tiga target guru di sekolah, yakni target kecil, target menengah, dan target besar. Target kecil adalah menjalani hari tanpa masalah di sekolah, target menengah ialah membuat siswa mempelajari pelajaran yang diberikan, sedangkan target besar adalah melihat para siswa sepenuhnya terlibat aktif dalam pembelajaran. 
Target besar adalah target yang dimiliki oleh guru profesional yang mandiri. Guru ini mencoba untuk melihat sebagian besar siswanya, sepenuhnya terlibat aktif dalam pembelajaran setiap hari. Lebih tepatnya, semakin banyak siswa yang melakukan pelajaran harian untuk menumbuhkan kemampuan DIESCA (Dignity, Energy, Self Management, Community, Awareness).

Dignity, siswa belajar dengan penuh kehormatan: berbakat atau tidak siswa duduk dan berjalan dengan tegak dan yakin. Siswa merasa yakin bahwa mereka bisa berhasil dan menyelesaikan masalah. Siswa merasa sangat yakin dengan harga dirinya. Energy, energi siswa mengalir dengan baik: siswa sibuk terlibat dan aktif, suasana di kelas sangat hidup, tidak ada yang memperhatikan waktu.Waktu seolah cepat berlalu. Self management, siswa mengatur dirinya sendiri: siswa membuat pilihan dan paduan yang benar, serta melakukan disiplin diri, memiliki kemauan belajar dan tekun. Siswa tidak perlu diperintah. Community, muncul kekompakan: siswa sering memperlihatkan perilaku, sering berbagi, bekerja sama, berbaik hati dan merasa saling mengandalkan, tidak ada perilaku antagonis, mengejek atau penolakan. Awareness, siswa berwawasan dan siap: siswa menunjukkan adanya konsentrasi belajar dalam anggotanya mengamati, mendengarkan, berfikir, memperhatikan, mengevaluasi, dan mencipta apa yang sedang terjadi. Mereka memiliki tingkat perhatian yang tinggi.

Guru profesional yang mandiri mengetahui kapan harus melakukan penyesuaian pada kegiatan mengajarnya dan tidak segan mencoba sesuatu yang baru, jika dirasa hal tersebut dapat membantu mereka di dalam menerapkan idealismenya.

\section{Peluang Bagi Perguruan Tinggi: Menyiapkan Calon Tenaga Guru yang Profesional}

Guru profesional tidak terjadi secara instan, tetapi bermula dari proses pengalaman akademik yang ditempuh. Penguasaan secara teoritis tidak cukup untuk memberi jaminan bagi guru untuk siap terjun di lembaga pendidikan. Sebagaimana yang lazim dilakukan oleh seorang guru dalam proses pembelajar, meliputi persiapan sebelum masuk kelas berupa pembuatan perangkat persiapan pembelajaran 
yang meliputi langkah-langkah pembelajaran. Ketepatan di dalam membuat desain atau rancangan pembelajaran merupakan sebuah skill yang membutuhkan proses pelatihan dan penguasaan beberapa keterampilan metodologis pembelajaran. Belum cukup sampai di situ, bahwa keberhasilan praktek di depan kelas dan keberhasilan mengorganisir siswa sangat tergantung pada kemampuan guru di dalam memahami langkah-langkah pembelajaran yang sudah disiapkan. Dibutuhkan persiapan yang matang. Akan halnya kurikulum 2013 yang secara substansial mengkondisikan suasana pembelajaran berbasis riset, maka pola-pola pembelajaran demikian seyogyanya dapat diantisipasi semenjak dini, salah satunya melalui lembaga tinggi khususnya yang konsentrasi pada penyiapan calon tenaga guru yang profesional.

Mata pelajaran agama Islam yang selama ini identik disampaikan dengan pendekatan konvensional, dibutuhkan improvisasi yang lebih variatif dan menggunakan teknik-teknik yang lebih memberikan peluang kepada peserta didik untuk lebih mendapat kesempatan berkembang. Karakteristik mata pelajaran agama Islam yang bersifat doktrinal diurai dan dikaji melalui perspektif riset, dan ilmiah.

\section{Kesimpulan}

Secara alami perubahan akan terus terjadi pada sebuah kurikulum. Misi besarnya adalah adanya situasi yang lebih baik bagi out put pendidikan. Perubahan tersebut secara substansial dalam rangka keseimbangan antara sikap spiritual dan sosial, rasa ingin tahu, kreativitas, kerja sama dengan kemampuan intelektual dan psikomotorik. Dengan keseimbangan tersebut diharapkan out put pendidikan lebih kompeten agar mampu menghadapi tantangan masa depan.

Terlepas dari itu semua persoalan tersebut, salah satu faktor mendasar adalah maksimalisasi terhadap pembekalan calon tenaga profesional guru sebagai instrumen penting dalam menyukseskan pendidikan. Adanya kurikulum 2013 tidaklah seharusnya menjadi momok yang menakutkan bagi guru. Untuk menyikapi hal itu dibutuhkan guru profesional, yang dapat menyikapi perkembangan kurikulum yang ada. Dalam konteks kurikulum 2013 sendiri, salah satu 
konsep yang bisa diterapkan oleh guru untuk mengembangkan potensi diri siswa adalah dengan menerapkan pembelajaran berbasis riset (penelitian). 


\section{DAFTAR PUSTAKA}

Ahmad, M. dkk. 1998. Pengembangan Kurikulum. Bandung: Pustaka Setia.

Anam, Saiful. 2006. Sekolah Dasar: Pergulatan Mengejar Ketertinggalan. Solo: PT. Wangsa Jatra Lestari.

Ashan, Mc. 1995. Competency Based Education and Training. Philadelphia: The Falmers Press.

Depdiknas. 2002. Pelakasnaan Kurikulum Berbasis Kompetensi. Jakarta: Puskur Balitbang.

. 2001. Kurikulum Berbasis Kompetensi Mata Pelajaran Pendidikan Agama Islam Sekolah Menengah Umum. Jakarta: Puskur Balitbang.

Fatah, Nanang. 2000. Manajemen Berbasis Sekolah. Bandung: CV Andira.

Hamalik, Oemar. 2006. Manajemen Pengembangan Kurikulum. Bandung: Remaja Rosda Karya.

Idi, Abdullah. 2007. Pengembangan Kurikulum, Teori dan Praktik. Yogyakarta: Ar-Ruzz Media.

Kwartolo, Yuli. "Catatan Kritis Tentang Kurikulum Berbasis Kompetensi", Jurnal Pendidikan Panabur, 1 Maret 2002.

Muhaimin. 2003. Wacana Pengembangan Pendidikan Islam. Yogyakarta: Pustaka Pelajar.

Mulyasa, E. 2002. Kurikulum Berbasis Kompetensi: Konsep, Karakteristik, dan Implementasi. Bandung: PT Remaja Rosdakarya.

. 2003. Kurikulum Berbasis Kompetensi. Bandung: PT Remaja Rosdakarya.

. 2006. Kurikulum Tingkat Satuan Pendidikan. Bandung: PT Remaja Rosdakarya.

Nasution, S. 1982. Azas-azas Kurikulum. Bandung: Jemars, 
Nasution. 1990. Pengembangan Kurikulum. Bandung: PT. Citra Aditya Bakti.

Sukmadinata, Nana Syaodih. 2005. Pengembangan Kurikulum: Teori dan Praktek. Bandung: PT. Remaja Rosdakarya,

Sumanta, Mulyani. 1988. Kurikulum dan Pengajaran. Jakarta: Departemen Pendidikan dan Kebudayaan Direktorat Jenderal Pendidikan Tinggi.

Susilo, Muhammad Joko. Kurikulum Tingkat Satuan Pendidikan: Manajemen Pelaksanaan dan Kesiapan Sekolah Menyongsongnya.

Tilaar, H.A.R. 1994. Manajemen Pendidikan Nasional: Kajian Pendidikan Masa Depan. Bandung: PT Remaja Rosda Karya.

UUSPN, No. 20 Tahun 2003, Bab 1 Ayat 19. 